\title{
The long journey of the rice maiden from Li'o to Tanjung Bunga: A Lamaholot sung narrative (Flores, eastern Indonesia)
}

\author{
Dana Rappoport
}

\section{Introduction}

The 'long songs'1 I have been working on in Indonesia, in both the Toraja and the Lamaholot regions, have a basic similarity: they tell the story of journeys. In the Toraja region (Sulawesi), they were called ossoran, from the verb mangosso' ('to tell in an ordered way, according to a succession'). They described the origin of something — an object (iron, a cordyline leaf), a human, a spirit (the bugi') —and recounted its progress from a distant place (the sky or elsewhere) to the site of narration in the human world. These were not genealogies, because there was no question of a succession of filiation. They were about journeys or peregrinations in space. These stories, in octosyllabic lines, performed through songs and dances during many days, bringing the whole community together, were banned by the

1 I use the expression 'long songs' to refer to sung narratives from 500 to 1,000 lines long at least. Some may extend to more than 10,000 lines and require six days and six nights of singing (cf. Toraja: Gelong maro). 
Christian authorities in the middle of the twentieth century. They have now fallen into oblivion except for the few that have been transcribed (van der Veen 1965, 1966; Rappoport 2009).

In the Lamaholot-speaking region (eastern Flores), the long songs also tell the stories of beings (humans or spirits) moving from one place to another. Several men can still sing and explain them. Unlike the situation in the Toraja region, among some of the Lamaholot, these long songs have not been eradicated, although they are now threatened due to literacy and lifestyle changes.

It would be interesting to extend the comparison to other populations of Insulindia (island Southeast Asia). From the route of the Bunaq ancestors (Berthe 1972) to the initiatory journeys of the heroes of Palawan epics (Revel 2000), it is likely that most of the long songs in Insulindia are based on the storytelling of paths and journeys. And more broadly, we may underline that even the famous long stories of Indo-European literature also have as their narrative springboard the quests taking place in space. Think of The Odyssey, Don Quixote and the story of the Holy Grail, to name a few, even though these stories were not sung. All of them raise the same basic interpretative questions. We want to understand the reason for the journeys and the geographical extent of the travel, with points of origin and points of arrival. What brings the journey to an end? Is it the final goal that is important or the journey itself? What do these trips teach those who tell them? Why is the content of these narratives so important for the societies that maintain them? What are the performance rules of their telling?

To address some of these questions, I look at a Lamaholot long song that I recorded in 2006 on the Tanjung Bunga peninsula, at the eastern tip of Flores, in the desa of Ratulodong (or Waiklibang). ${ }^{2}$ The conditions for recording this narrative were surprising. I was called in November 2006 to attend the Dokan Gurun ritual, which means literally 'to wrap, to protect'. The ritual began in the village's 'big house' (lango bélen'). On the altar, stained with goat's blood, sat three main clan leaders next to a young woman around 20 years old. I would understand much later

2 My thanks go to the singers of the villages of Waiklibang and Waibao who have shared with me, since 2006, part of their ritual life, part of their knowledge and part of their time. I also want to warmly thank my faithful friend Philip Yampolsky, who edited the English version of this article, and James Fox for his long-inspiring reflections and his invitation to write in this volume. This research is part of various fieldwork done since 2006 with the permission of the Indonesian Government. 
that she embodied the figure of the rice seed to be wrapped in the granary (inside the 'big house' in this village). Everyone went to the yard in front of the house around $11.30 \mathrm{pm}$ and began to sing and dance the 'long song', which lasted until early morning. I was able to record the whole session, without any battery failure. The singers danced around the ceremonial nuba nara stones (considered the seat of the rice maiden) in a counterclockwise direction. Some songs were performed by men, others by women, but from song to song, piece by piece, the entire narrative was told. At daybreak, during the last song, all the women who were singing, including the young woman I had seen the previous day, were wrapped in single file by the ritual leader (a single wrapping enveloped all of the women) in a very old Indian cloth (ketipa réda), and were then led into the house where the rice granary was located. The young woman was therefore the embodiment of the rice seed that was to be wrapped and placed in the storehouse before sowing.

In this chapter, I analyse the content of the song that was performed that night - the story of the origin of rice- together with its oral performance. This Lamaholot narrative has already been the subject of a few studies (Tukan 1996; Kohl 1998). As it can be told in different forms, in its entire ritual sung version or in summary narrative versions without song, the story can vary in length and the steps and the end of the journey vary widely from village to village even though the place of departure is the same (Li'o). ${ }^{3}$

Variation is one of the common features of the oral tradition. In the eastern Insulindian region, aesthetic variability seems to be at its height, in terms of both style and content. On the Tanjung Bunga peninsula alone, more than six musical styles are counted. Add to this the intense dialectal variability. It is therefore not surprising that versions of the same story are different in realisation yet similar in outline. This inexhaustible variability—already noted a long time ago — is one of the great attractions of this region (Adams 1971). The version collected in its summarised form (and not sung) by Karl-Heinz Kohl (1998) in the neighbouring village of Waiklibang (20 kilometres away) is very different from the full sung version I recorded (I will not detail the similarities and differences here).

3 Li'o (also written Lio) is in central Flores, west of Sikka, around Paga and Dondo. It is both the name of a region and the name of a linguistic group of around 100,000 speakers, according to the census of 2009 (Eberhard et al. 2020), and is considered a dialect chain with Ende (Grimes et al. 1997: 85). 
Similarly, if singers of the village where I work are asked to summarise the story, they will not give all the elements of the myth, and their versions will vary even from one singer to another. Often, they add elements that are not sung in the versified story, which is why I must constantly go back and forth between the lines sung that night and the summaries made by the people, together with the observation of rituals and people's feelings towards rice.

First, I will look at the topic of the journey inside the song of the origin of rice itself. Then I will describe the performative aspects of this song. Finally, I will consider the time of this long journey and the way it is expressed in the song.

\section{Paths and journeys in the song of the origin of rice}

\section{Road songs in Lamaholot culture}

Road songs are a useful ethnomusicological category, for at least two reasons: on the one hand, because in the Lamaholot area, songs performed while walking are common, and on the other, because songs that narrate paths and journeys, performed while dancing, are also prevalent. These two types of road songs differ in their duration (the former can be termed 'short songs', while the second corresponds to 'long songs'), but they are related because they are part of the same ritual: the first, called 'road song' (berasi pana laran), is performed before the second, which is sometimes called 'narrative of the road [of someone]' (opak moran laran).

At Waiklibang, great rituals (involving more than one clan) begin with road songs, sung literally on the road. On their way to the ritual, men sing two-by-two as they walk along the road towards the place of the ritual (whether to the 'big house' or to the ceremonial rice field). ${ }^{4}$ This song is a male vocal duet (a pair of singers), a tight and technically difficult counterpoint, which is on the verge of extinction because of its required virtuosity and the decline of all traditional vocal forms. The rhythm is unmeasured. The men's high and sharp voices overlap at close intervals

4 Each sovereign clan is in charge, alternately, of a ceremonial rice field each year in which animal offerings, songs and dances will take place. 
(smaller than a tempered major or minor second). ${ }^{5}$ The singers make their voices echo from the mountain. Why do they sing while walking? First, to notify those who have already arrived at the dance square. The host clan hears its guests from afar and prepares for their arrival. ${ }^{6}$ But this repertoire is not only an announcement, it is also, above all, a request for permission to pass in front of the dwelling places of nitun, the spirits who live in the tall trees and in certain features of the landscape. The song tells about the places passed by the singers. The words differ according to the calendar. Here is an example of lines sung while walking:

\begin{tabular}{|c|c|}
\hline Duli pi’in osé Munak Ina & $\begin{array}{l}\text { This site here is called Mother } \\
\text { Monkey }\end{array}$ \\
\hline pali Pao Laka Dodo & site Mango Laka Dodo \\
\hline Duli pi’in déo dase & This site is almost reached \\
\hline ni piin di no'on naran & this site with a name \\
\hline Lei ka'an lali pana laran & $\begin{array}{l}\text { My legs walk on the path of the } \\
\text { setting sun }\end{array}$ \\
\hline lei lali pana laran & $\begin{array}{l}\text { legs walk on the way to the } \\
\text { setting sun }\end{array}$ \\
\hline Pana kala hiko waén' & Walking, crossing what's in front \\
\hline gawé liwa lolon & passing through the summit \\
\hline Duli be'ena' tana & This site a landslide land \\
\hline pali balébo-lébo rié & site of water-inundated poles \\
\hline Luat buno ha'é & If we maybe go down \\
\hline pana ka’an tiro léwo & walking to the village \\
\hline
\end{tabular}

Source: Berasi Pana Laran song, Waiklibang, 2006.7

Once the request for permission to pass has been issued, the singers continue on their way. No manifestation of permission is expected from the singing, except ease of travel on the road, which is a positive sign of protection. The lyrics of this kind of song are made up of toponyms and

\footnotetext{
5 Thirteen examples of this kind of song can be listened to at: archives.crem-cnrs.fr/archives/ items/CNRSMH_I_2007_006_001_208/.

6 A singer explained to me: 'In the past, when there were rituals like this, when we went to the place of the ritual, we had to sing the berasi pana laran, so people would say, "Hey, they're already there, here they are." From a distance, they prepared the betel. We would sing to the door of the house. In the song itself, we said: "Prepare the areca nut."

7 '(Flores Waiklibang) Men's Duo “Chant De Route” 1', Sound Archives, available at: archives. crem-cnrs.fr/archives/items/CNRSMH_I_2007_006_001_208/.
} 
places (duli pali) with metalinguistic expressions of a performative type describing the singers walking on the path. When the singers arrive at the performing place, they will, at night, begin the second type of 'road song', not by walking anymore but by dancing until dawn.

The second type of road song consists of long sung narratives, called opak bélun ('singing narrative') or opak lian naman ('singing narrative with songs on the dancing place', as they are most often danced in village dance squares). ${ }^{8}$ Their content varies according to each village and each ritual. In Waiklibang, these 'long songs' tell of journeys, linked to the origins of rice, sovereign clans or, less often now, sharp weapons (when villages went on raids). Their importance in the Lamaholot region may be related to the way this area was populated, through waves of migration from the west (Sina Jawa), from the east (Keroko Pukén) or, more rarely in Tanjung Bunga, from the north (Seram Goram). ${ }^{9}$ In consequence, in a village, the various clans come from different points of origin, but on the ritual communal house, one origin is indicated through the position of the head of the crocodile on the top of the house. The crocodile points to the place of origin of the main sovereign clan (tana alat).

This opak lian naman repertoire is distinguished by the length of its narratives, the length of the performances and the intense participation of people during these long night vigils that bring together all the clans of a ceremonial domain (lewo tana: 'village land'). A 2,000-line song in hexasyllabic distichs is performed until dawn; there are no narrative stops in the middle of the night and the song must end when the day is up. All these narratives-for rice, clans or war-recall journeys (of the rice maiden, of ancestors, of spirits). The memory of the routes is fixed by the recitation of sequences related to migration, referring to placenames enunciated in a fixed order-places that can be written on a map (Map 7.1).

8 They are also called opak hodé ana' ('sung narrative with duets') or mura lian ('lively songs'). Opak ('storyteller'); Bélun, always paired with opak, means 'to sing' (Pampus 2001). Hodé' ana' ('to receive the child') is the name of the two duets in the form of an interlude within the narrative. Lian means 'songs, singing'.

9 These three names are constantly told by the various clans, coming from one or the other places, which designate mythical origins. These are the names of mythical places, always cited by the various clans as their place of origin. 


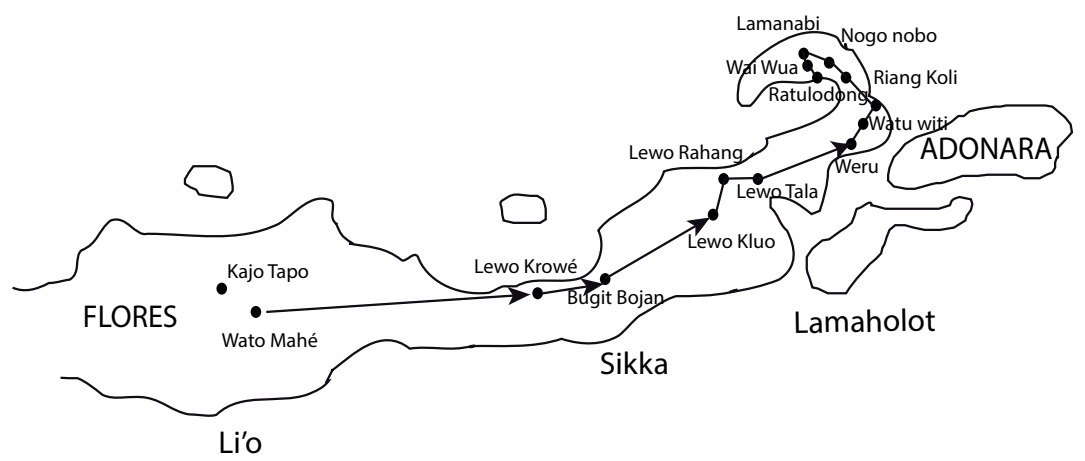

Map 7.1 The journey of Nogo Ema' according to the sung narrative (Waiklibang, 2006)

Source: Dana Rappoport.

\section{The various paths in the song of the origin of rice}

Sometimes referred to as 'the narrative of Tonu Wujo's road' (Opak moran laran Tonu Wujo), after one of the names of the maiden who will turn into rice, this song of the origin of seeds develops a myth widespread throughout island Southeast Asia in many variations (Mabuchi 1964): the killing of a human (child, woman or man) who will turn into edible plants. While the motif of the personification of the seed is found from Southeast Asia to Oceania, it is in eastern Insulindia that it seems to be most widely developed. Not only is it danced and sung, it is also sometimes enacted by humans, who personify the seed. Among some Lamaholot of eastern Flores, a maiden is chosen each year to perform the role of the victim, who, in the story, will be transformed into rice and maize (the young woman I saw at the altar); her presence is not only real during the ritual but also materialised each year by artefacts that, for the most part, will last only a year (a stake and a stone altar, representing the place where she will be killed in the rice field; fabrics and objects representing her comb and hair oil). ${ }^{10}$

10 In its agrarian function, méran bélédan refers to the sacrificial altar on which the maiden, who will embody herself in rice, sits before being sacrificed. This altar is made of a stone (méran), depicting the young woman's seat, and a stake (belegat), depicting the backrest, topped with a coconut with which to wash the young woman's hair and covered by a shelter constructed in the rice field (mau Tonu Wujo) (Rappoport 2017). 
AUSTRONESIAN PATHS AND JOURNEYS

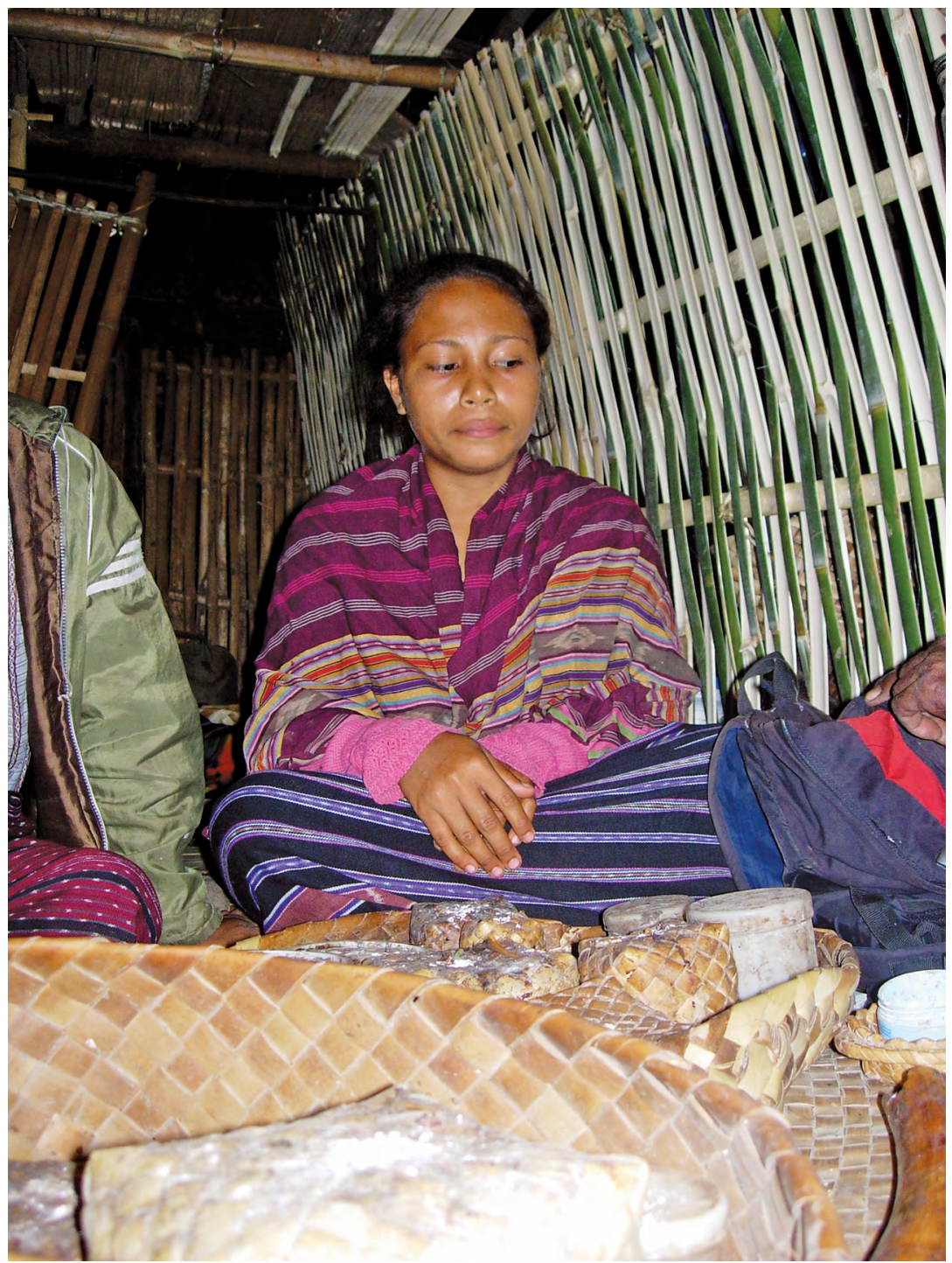

Plate 7.1 A rice maiden, dokan gurun ritual, Waiklibang, 2006

Photo: Dana Rappoport. 
7. THE LONG JOURNEY OF THE RICE MAIDEN FROM LI'O TO TANJUNG BUNGA

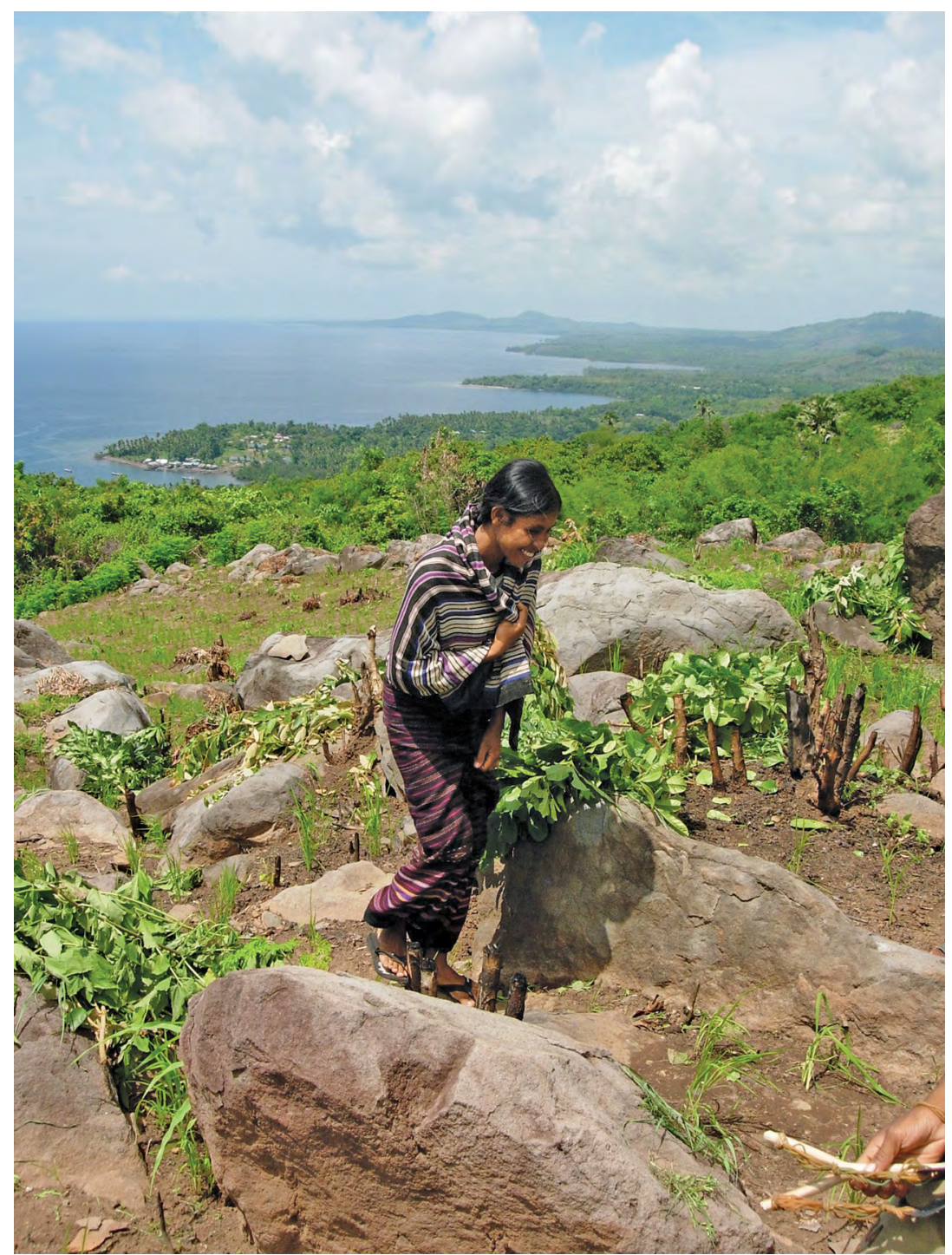

Plate 7.2 A rice maiden, helo nikat ritual, Waiklibang, 2007

Photo: Dana Rappoport. 


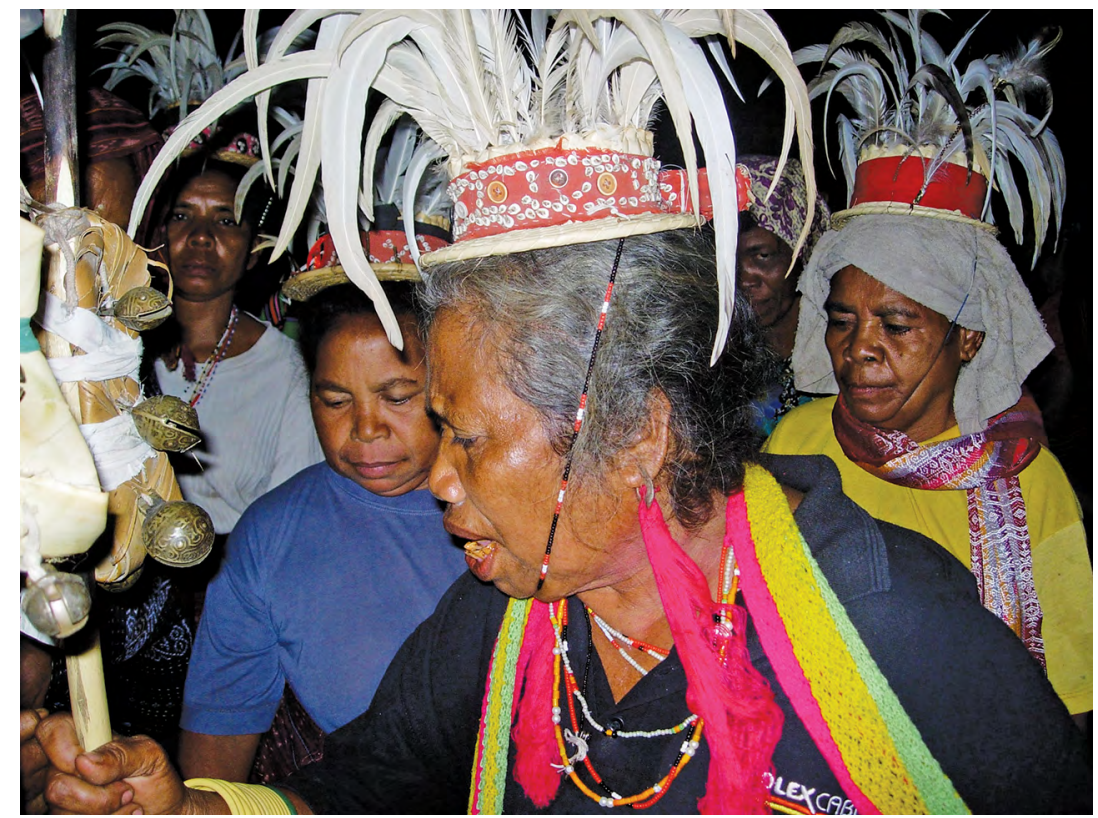

Plate 7.3 Ema' Klara Kesi Liwun, the opak narrator, performing the song of the origin of rice, 2006

Photo: Dana Rappoport.

This song of the rice origin is organised around an essential issue: the survival of a society threatened with famine. In the past, humansignorant of agriculture-were hungry; they ate beans, ingested their own excrement and drank their own urine. To ensure the survival of the group, a maiden known as Nogo Ema' (or Tonu Wujo) ordered her seven brothers to find machetes, cut down and burn all the trees in the field and then kill her. Stabbed to death by her youngest brother, her body metamorphosed eight days later into rice and other edible plants. From the harvests of this field, the brothers filled seven granaries; with the sale of this rice, they bought elephant tusks (to get married). So, a woman 'paid' for seven brothers so that they could take wives. But these seven brothers no longer got along and fought, which is why Nogo Ema' left to be shared in all the villages. ${ }^{11}$ This is the crux of this sung story.

The sung narrative that I recorded during the night of the Dokan Gurun ritual is called Opak bélun gurun gawak béola tugu ('The narrative of the wrapping up of the results of working in the fields'). It comprises

11 Although the body of Nogo Ema' is dead, she keeps living in another form. 
more than 2,200 lines (hexasyllabic and octosyllabic) arranged in four parts: ${ }^{12}$ 1) The life of Nogo Ema's male ancestor, with a quest for a child (Pati Sogén) and the quest for his future wife in the Li'o region (lines $1-500)$; 2) the family of Nogo Ema' with her seven brothers and the invention of agriculture by Nogo Ema' (lines 501-1,270); 3) the killing of Nogo Ema' and transformation of her body into a plant (lines 1,271-437); and 4) Nogo Ema's journey and her unfortunate adventures (lines 1,4382,268 ) and her arrival at the place of enunciation of the story (from 1,982 to the end). While the first half of the story is devoted to the ancestors of Nogo Ema' and unfolds over more than 1,000 verses, the dramatic knot about the killing and transformation of the maiden into a plant appears only halfway through (sung in 100 verses), after which the journey to and arrival at the village of enunciation take place over 800 verses.

It should be noted that, throughout the song, this maiden bears several names. She is most often called Nogo Ema' or Tonu Wujo, and more rarely Bési Paré Nogo Gunun, Nogo Gunun Ema' Hingi or Biné’ Bési Ana' Paré ${ }^{13}$ (shortened to Bési Paré when she metamorphoses into edible plants, in line 1,404 and after). ${ }^{14}$ Biné ana' is also a kinship term used to name her. Until the end of the song, she appears mainly under the two names Nogo Ema' and Tonu Wujo. This striking multitude of names can be explained by the constant metamorphoses of this young woman, whose status varies with her roles as a child (ana'), a girl (Nogo or Tonu) ${ }^{15}$ a sister (biné), a woman (ema'), a plant (Bési Paré) or a spirit (Tonu Wujo, Nogo Ema').

I will consider now two sequences of the narrative that unfold two paths: a downward path and an eastward path.

\section{The downward path to the ancestors}

The first part of Nogo Ema's narrative (lines 1-500) concerns the period of cultural foundation, when humans were still only 'earth spirits' (nitun). This period, evoked by the naming of places and of Nogo Ema's ancestors

12 This narrative has been written down by a team I gathered during one week, comprising a storyteller accompanied by two singers and a script (teacher from elementary school). The text was then translated to Indonesian by a teacher from a secondary school.

13 Biné' ('sister on the father's side'), ana' ('child'); biné' ana' is a kinship term that can designate the father's sister's child.

14 Bési ('pumpkin'); paré ('growing rice').

15 A name that can be given to girls or women. 
over four generations before her, covers, on the one hand, the sterility problem of her paternal grandparents and, on the other, her father's search for a wife. So, two initial conflicts set the characters in motion: the longing for a child in the grandparents' generation and the quest for a woman in the parents' generation. These quests determine the spatial progression in search of a child and a woman.

The narrative therefore goes back a long way in time and space. It begins in a place on the border between the Li'o-speaking country and the Sikka country, 200 kilometres west of Tanjung Bunga. The distant land (tana léla, says the poem, circa line 1,140) is evoked as follows:

Tonu ukut lewo doan

Wujo raran tana léla
The traces of Tonu lie in a distant village

the path of Wujo is a remote land ${ }^{16}$

Source: Excerpt from the song Opak bélun gurun gawak béola tugu, lines $1,139-1,140 .^{17}$

Throughout the first part of the narrative, the story takes place in Li'o, between the two villages of Nogo Ema's grandparents: that of her paternal grandparents (named 'Village of the Altar Stone, Land of the White Bamboo') ${ }^{18}$ and that of her maternal grandparents (named 'Village of the Coconut, Land of the Areca Nut'). ${ }^{19}$ Whereas the first is on the Earth, the second is located underground and is populated by humans and spirits (nitun) in the place of the setting sun. The place of her paternal grandfather is recalled in the name of the ceremonial domain, ancestors, ceremonial stones, spirits, mountains and lands:

16 Lamaholot poetry relies on pairs of words that are complementary, synonymous or antonymous. These pairs are disjunctive when they are sung (in the above lines: Tonu/Wujo, ukut/raran, lewoltana, doan/lela). Ukut raran literally means 'the trace of the path, the memory of the road'.

17 All the following quotes are taken from the narrative I collected on 8 November 2006. The whole narrative can be heard in eight audio files at: archives.crem-cnrs.fr/archives/items/CNRSMH_I_2007 _006_001_232/.

18 Lewo Wato Mahé Tana Belan Burak.

19 Kajo Tapo Wua' Poné. The entire name is Lewo Lali Kajo Tapo Tana Lali Wua' Poné ('To the Setting Sun Village of the Coconut, to the Setting Sun Land of the Areca Nut') (lines 175-76). All place and character names have simple and elaborate forms. The simple form requires only the first words (so the villages are usually called Wato Mahé and Kajo Tapo), as in Rote island (Fox 2006: 91). 
Lewo Wato Mahé

Tana Belan Burak

Raja Pati Mangu

Tuan Boli Li'o

Tonu Osé Longo

Wujo Laju Burak

Nuba Sogén Sara Boro

béla Kéwa Kala Midi

Guna Siga Buga

déwa Tuli Nara

Ilé Wato Téna

Woka Wai' Wuri

Duli Kebo Lolon Buto

pali Hulu Hala Lolon
Village of the Altar Stone ${ }^{20}$

Land of the White Bamboo

Raja Pati Mangu

Sovereign Boli Li'o

Tonu Osé Longo

Wujo Laju Burak

[Stone] Nuba Sogén Sara Boro

[stone] béla Kewa Kala Midi

[Spirit] Guna Siga Buga

[spirit] dewa Tuli Nara

Mountain of the Stone Boat

Mount of the Wuri River

Site of the Eight Palms

Site of the Warm Leaves

The places inhabited by humans are defined by the association between a toponym (lewo tana), a patronym of a sovereign (raja tuan), ceremonial and potent stones (nuba béla), auxiliary spirits (guna déwa), a mountain (ilé woka) and a site (duli pali).

The story begins with a quest for a child and a quest for a wife. In the paternal village (Wato Mahé), a couple, in despair of sterility, adopts a baby boy, Pati Sogén, who had been abandoned in the forest. Later, when Pati Sogén has become a young adult, sitting in the temple and playing a flute, the flute tells him to go to the Coconut Tree village (Kajo Tapo) to choose his wife, who is Koka Tuli Sanganara's daughter. He goes there, far away. Upon arrival, his bride, Gowin Burak, asks him to go to meet her grandparents, who are underground spirits (nitun). The task looks difficult because their place is located on a precipice. So Pati Sogén thinks about it, and a rat (or snake/chicken) appears to help him get underground (ula rogo nolo, manuk béka doré: 'the snake moves forward, the chicken follows', line 474). The animal, which is an auxiliary spirit (guna déwa),

20 Mahé means the trace of a landslide. This word is also found in the neighbouring Tana 'Ai region with the grén mahé ritual-mahé referring to an altar of stone and wood (Lewis 1988a: 32). 
helps him to break the stones, and there he discovers two villages ${ }^{21}$ whose ruler has the double male-female name Ina Rimo Ama Gaja. To take a wife, he is only asked to eat and drink with them in mind. Thus, Pati Sogén Laga Li’o (Nogo Ema’s father) marries Tonu Gowin Burak Bubu Jawa Rérek (Figure 7.1).

The path Pati Sogén has walked goes from the Earth to the world below-that of the underground spirits. The motion is vertical. From the beginning of the narrative, the toponyms are overwhelming and there are no temporal indicators. The names of villages, mountains, rulers and cultivated fields and the mention of attributes of sovereignty-ceremonial stones planted (nuba nara) and mobile auxiliary stones (guna déwa) refer to an ancient time, that of Nogo Ema's grandparents.

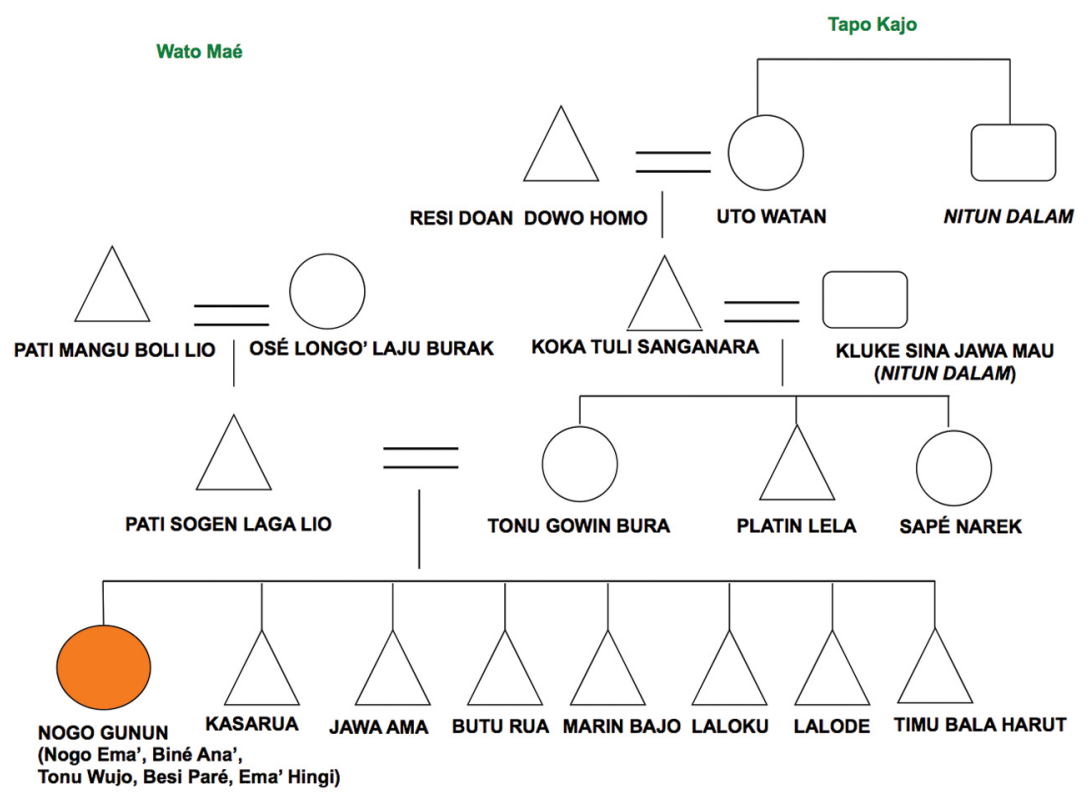

Figure 7.1 The ancestors of Nogo Ema' according to the narrative (Waiklibang, 2006)

Source: Dana Rappoport.

21 Sodok Lewo Bélen', Tana Haban Wawe Utan ('Great Mountainous Village, Dangerous Wild Boar Land'), whose sovereign is Ina Rimo Ama Gajak. 


\section{The eastward path to Tanjung Bunga}

In the last part of the narrative (from line 1,438 to the end), Nogo Ema', after her death, leaves Li'o, the region of her ancestors, to share herself from village to village. The song does not say in what form she leaves. Some say she goes in her invisible spirit form, but as soon as she arrives in a village, she transforms herself into a young woman. A remarkable feature of the story is Nogo Ema's constantly changing state and her continuous progress eastward.

What is the first reason for her departure? Why does this young woman's spirit leave her brothers? In Kohl's $(1998,2009)$ study, first published in German and then in Indonesian, the author uses the term 'wandering' (Ind.: pengembaraan) to describe the journey. Is it a wandering or a purposeful journey? In the song I recorded, the maiden moves eastward, towards the rising sun, towards the village of the storyteller, without wandering. The reason for her departure is given in the song: thanks to the harvest resulting from her metamorphosis into rice, her seven brothers fill seven rice granaries, allowing them 'to buy elephant tusks' (hopé bala) to 'buy a wife' (hopé wéli). But they quarrel, both outside and inside the house, which causes Nogo Ema' to flee:

\begin{tabular}{|c|c|}
\hline $\begin{array}{l}\text { Lodo mala geni wekit } \\
\text { géré mala guat onet }\end{array}$ & $\begin{array}{l}\text { They go down and fight }{ }^{22} \\
\text { they come up and tear each } \\
\text { other apart }\end{array}$ \\
\hline Na'a pali ata pito & The seven brothers \\
\hline ama pali ata léma & the five brothers \\
\hline Nogo nala ikit léin & Nogo goes on her feet \\
\hline Ema' nala hajan lima & Ema' wings her arms \\
\hline
\end{tabular}

The last distich, 'goes on her feet, wings her arms' (a common refrain in the song), indicates the departure of the rice maiden, without any other words. Human pride results from prosperity, which fosters rivalry and encourages the brothers to compete for goods and women. Shame and disgust at her brothers' actions are what drive Nogo Ema' to separate from her family, as Bapa' Krowés explanation shows: 
The brothers asked their mother: 'Mother, there are seven of us and there is only one daughter, so who is responsible for the bride price?' She said that, with the result of the harvest, they could each buy elephant tusks. The harvest of the field was endless. For a year, the harvest lasted, they harvested and it continued. In the end, with this success beyond all expectation, pride went to their heads. They felt superior. Nogo Gunun, in her form of rice, but also as a human being, was saddened. 'For my sake, they became proud. I will go away, I will go from one village to another.' Then she left in the form of an invisible spirit. From time to time, we either saw her as a human being or we didn't see her. And when she arrived at a village, then she took on her human form. (Bapa' Krowé, Personal communication, Waiklibang, July 2018)

Nogo Ema's departure is the beginning of a long journey, which will be marked by stops in the villages she encounters, from Li'o to Tanjung Bunga. The route she takes runs from west to east, from the Li'o country to the eastern tip of Flores (Map 7.1), passing through different places with long names. ${ }^{23}$ For example, Lewo Rahan, a village on the coast opposite Tanjung Bunga, is mentioned as follows:

$\begin{array}{ll}\begin{array}{l}\text { Lewo raé Tapo Toban } \\ \text { Tana Lewo Rahan }\end{array} & \begin{array}{l}\text { Village upwards of the Fallen } \\ \text { Coconut }^{24}\end{array} \\ \text { Laken wai lau } & \begin{array}{l}\text { Land of the Coconut Basket } \\ \text { whose name is River Seaward }\end{array} \\ \text { Raja Merin Miten } & \text { Raja of the Black Stone } \\ \text { Tuan Ina Rua } & \text { Sovereign of Two Women } \\ \text { Raja Butu Rua } & \text { Raja Butu Rua } \\ \text { Rua Marin Bajo } & \text { Rua Marin Bajo }\end{array}$

Each village name refers to a ceremonial domain (lewo tana) associated with a sovereign (raja tuan). Nogo Ema's journey is marked by her meetings with different rulers, almost all of whom want to have intercourse with

23 Here are the various village names told in the song: Lewo Krowé Tana Tukan Henga Rua Hama (around Maumere), Lewo Peli Bugit Bojan Tana Peli Tulé Walén, Lewo Keluok Wojon Tobo Tana Napen Hapén, Lewo Raé Tapo Toban Tana Lewo Rahan, Kawaliwu, Lewotala, Oka, Wéru, Watuwiti, Riang Koli, Lamanabi.

24 Line $1,496 \mathrm{ff}$.

25 The names of two rulers at Lewo Rahan. These two names, Butu Rua and Marin Bajo, are the names of two of Tonu Wujo's brothers (see Figure 7.1). 
her. Twice she is almost raped (in Lewo Rahan and Ratulodong) and twice she is raped (in Lewotala and Riang Koli). In Lewotala, she is raped at night by the sovereign Raja Nara Boki, inside the temple. In the poem, the word 'rape' is never sung:

$\begin{array}{ll}\begin{array}{l}\text { Pati bunu bauk } \\ \text { beda nodo nokok }\end{array} & \begin{array}{l}\text { When it gets dark } \\ \text { in the deep of night }\end{array} \\ \begin{array}{l}\text { Teka nala pali } \\ \text { buno nala pera }\end{array} & \begin{array}{l}\text { Wants to make a friend } \\ \text { needs a relation }\end{array} \\ \begin{array}{l}\text { Raé koké tukan } \\ \text { teka raé balé bawan }\end{array} & \begin{array}{l}\text { Up in the middle of the temple } \\ \text { up in the centre of the ritual } \\ \text { house }\end{array} \\ \begin{array}{l}\text { Tonu mia mata } \\ \text { Wujo rure eret }\end{array} & \begin{array}{l}\text { Tonu is ashamed } \\ \text { Wujo shows an undone face }\end{array} \\ \text { Lutu nala bai } & \text { Pregnant with a baby } \\ \text { nara nala béda } & \text { waiting for a child }\end{array}$

From this rape in the ritual house, a child is born whom she chooses to abandon; she places him in a shell and sends him to the sea, from the coast of Flores to Adonara. Beached on the opposite coast, the child's crying is confused by the people of Adonara with the sound of a great man. The child is then killed by them (around line 1,558), which explains why rice did not spread to Adonara, the neighbouring island. Once killed, the baby is pushed back to where it came from, stranded at Watuwiti and buried by the local ruler, which is why they attribute good harvests to this village. Nogo Ema', for her part, continues on her way and is raped again, at Riang Koli. This time, rape is represented by the donation of areca nut:

Ikit nala lein téna

tiro nala lewo

Koli Tana Wutun

Lajo Ekan Wakon
Moves fast on her $\operatorname{legs} s^{27}$

arrives at the village

Koli, the End Land

at the Lajo Land ${ }^{28}$

28 Complete name of Riang Koli’s village. 


$\begin{array}{ll}\begin{array}{l}\text { Raja Bési Burak } \\ \text { Tuan Talu Wai }\end{array} & \begin{array}{l}\text { Raja Bési Burak } \\ \text { Sovereign Talu Wai }{ }^{29}\end{array} \\ \begin{array}{l}\text { Soron wua hiku } \\ \text { nein malu padak }\end{array} & \begin{array}{l}\text { Gives an areca nut } \\ \text { gives hungry touches her hand }\end{array} \\ \text { Nogo mia mata } & \text { Nogo is ashamed } \\ \text { Ema' rure eret } & \text { Ema' shows an undone face } \\ \text { Hiko nala tion } & \text { Continues on her way } \\ \text { liwat nala gete } & \text { going on her way }\end{array}$

The rape is never told, only suggested through a litotic expression specific to this type of poetry. From this new rape, she gives birth not to a child but to rice itself. She continues her journey to Lamanabi where different events happen. When she climbs a mountain and observes the surroundings, she goes swimming and takes off her ring (line 1,599). Throughout the journey, Nogo Ema' loses objects: bracelet, ring, comb. The villagers of Muleng, while hunting, find the ring. By this means, they recover some of the harvest. ${ }^{30}$

Never feeling comfortable in the places through which she passes, but vulnerable, Nogo Ema' continues on her way to the narrator's village. There, she meets the narrator's ancestor, more than 14 generations earlier, and a new adventure occurs. The ancestor of the Maran clan (Raja Kélu Béra Tuan Bélawa Burak) meets the young woman while hunting. He tries to abuse her, but she deflects his attention by playing a trick on him, making him believe that a scorpion was there and the village was burning. Then she disappears. The next day, his dream tells him to return to the place where he met her, to the stone where she sat (Nogo méran: 'the woman's seat'), and when he returns he finds her golden earrings. In his dream, he is asked by Nogo Ema' to replant them, and the harvest from this planting is exceptional and, above all, endless. However, the ruler of the neighbouring ceremonial domain (Lewotala), who had raped and impregnated Nogo Ema', hears about this extraordinary fact and comes to see the harvest. He sets fire to it and Nogo Ema' disappears again.

29 Complete name of Riang Koli's ruler.

30 So, every time they leave to sow, these inhabitants give food to the ring. Nogo Ema's objects are kept in traditional houses and are fed. 
Here ends the story of Nogo Ema' in the sung version of the myth, on the evening of the wrapping of the maiden to enter the storehouse. But in fact, a continuation was told to me by Bapa' Krowé in 2018:

Once she disappeared again, Nogo Ema' ascended to heaven, at a place called Bubu Loti Bui Lomek, without being able to go down again. For 300 years (six generations), the population suffered from hunger. One of their ancestors, Bapa' Béra, sought a solution. And once again, an animal assistant made it possible to go up to the sky to search for her. He flew up to heaven in an attempt to bring her down. He talked to her, cut her hair while Bapa' Bera stayed down below. When she fell from the sky, he caught her. She turned into an egg. He told her not to turn into a chick and to stay inside. He told her that he would feed her eggs. He told his brother to go hunting to meet her. His brother went hunting in Kung Belen' and found a grain of rice in the belly of a deer and replanted it. Since then we have been growing rice and the Maran clan has shared it with all the others for at least 300 years. Bapa' Hawan and Bapa' Bera (ancestors from the Koten and Maran clans from Waiklibang village) found it, cultivated it and shared it. They lived in a single house up there (in the old village). There were seven of them in Béra's family, and seven in Hawan's family. We became the Koten clan and the other Marans. The rice journey is more or less that. (Bapa Krowé, Personal communication, July 2018)

Despite the fantastic and cryptic aspects of the story, several generations of the narrator's ancestors emerge in the song. The following are mentioned: Pati Puru Hawa, Pain Béra Jon Nara, Kélu Béra and Sédu Dowé Dua Ama. Myth is then connected to lived reality; fiction and history intertwine.

Why sing and tell about the rice maiden's journey? Attending the ritual, one realises the importance of the act of wrapping the seed so that she does not leave again. A common fear is that the seed will go away; in the story, Nogo Ema' is constantly disappearing. The farmers' wish is to wrap her up, to keep her, to protect her, to do everything possible to prevent the seed from leaving again, which would risk leading them to starvation.

A singer explains to me that this narrative is a way to welcome the rice maiden:

We want to welcome Tonu Wujo to her village of origin. So, we go there by flying, not by walking. Once there, we move hither and thither by walking, from Li'o to eastern Flores, so the story which ends in the village begins with recounting her clans, her 
temple, her beach; we tell of her mountains, her spirits [nitun], her days; we tell everything, we must not make a mistake. That's why only one man knows it. If many of us know it, there will be war because nobody likes to be defeated. (Storyteller Anton Siku Mukin, 68 years old, Personal communication, Karawutun, March 2006)

The sung narrative fixes the memory of routes through the recitation of sequences of placenames linked to migration, referring to a historical knowledge of these places, which are evoked in an unchanging order.

\section{To tell the rice maiden's journey}

During an agricultural year, the narrative of the rice maiden's journey is sung four times: before sowing, harvesting, threshing and storage. A large number of people from the different clans of the ceremonial domain gather for a long musical vigil.

\section{One narrative through various dances}

The 2,200-line narrative of the origin of rice is conveyed in a number of distinct musical forms, performed alternately by men and women. Several storytellers will sing, following one another, from $11.30 \mathrm{pm}$ to $6 \mathrm{am}$, according to a succession of narrative sequences sung to six different dances. Each is distinguished by its name, its variety of steps, its melodicrhythmic configurations and its choreographic structures (disjointed centripetal line, circle, semicircle, separate bodies and so on). The various genres are named haman opak bélun, nama nigi, lian kenolon and nama néron, goken, berasi. ${ }^{31}$ Most can be sung several times during the night. All involve few singers-only six or seven-according to a complex alternation: a storyteller (male or female: $o p a k$ ) and his or her 'embroiderer' (nukun opak), ${ }^{32}$ two pairs of singers (hodé' ana') and sometimes a soloist (nukun blaha). Thus, whereas the story is continuous, the songs made to tell it are discontinuous, even though the variety of musical genres never breaks the narrative continuity.

31 Compare with the sound files at: archives.crem-cnrs.fr/archives/items/CNRSMH_I_2007_ 006_001_232. For the succession of the dances, see Rappoport (2016: 184).

32 A duet cannot mix male and female singers. Thus, if the storyteller is a female, the embroiderer must also be a woman. The Maran clan had a female storyteller, but she had recently passed away. 
I would like to focus on the most important musical genre and dance common to the whole of eastern Flores. The dance is the same everywhere: it is performed by a chain of dancers adorned with white feathers, moving counterclockwise. ${ }^{33}$ It is usually called haman opak bélun, which means 'to thresh to sing the narrative'. This is the famous dance of the Tanjung Bunga and Bai Pito areas, recognisable by the clothes of the dancers, who stand in a row with feathers and bells on their backs and feet. The dance has been partly described by Ernst Vatter (1932) and Jaap Kunst (1942: 7). Vatter also recorded a silent movie of the dance in 1929 (Vatter 1963). In this, the ground is threshed (haman) in the place of the dance (naman) and a narrative is told (opak) in a lively song (mura lian). The name of the dance itself shows that it is much more than a series of motions; it is a ceremonial narrative. Unlike all the other main round or chain dances of the neighbouring areas, in which the dancers hold hands or arms (like the dolo-dolo, lilin and lian naman on Adonara), the haman opak bélun is performed in a chain without holding hands. The dancers stand in a semicircle, while the singers stay inside the circle and move around the ceremonial stones (nuba nara). All move in a sequence of six steps, performed all night—left, right, left, right, right, left—in an obsessive circular motion. The pulse is beaten on the ground and marked by bells. On the last beat, there is no threshing; rather, it is almost mute. What is important in the dance is the motion of the pelvis, which is visually and sonically emphasised by bells, chains and shell decorations_all of which reinforce the energy conveyed.

Two things are important to keep in mind: the variety of dances does not interfere with the continuity of the story (the story is paramount), but without dance there is no other possibility of telling the narrative (that is why in regions where storytellers have disappeared, the dance also disappears). Narrative, songs and dance are intrinsically linked.

33 This could be related to the way the rice fields are harvested. The harvesters are arranged in a single line that progresses from left to right to surround the divinity of rice, represented by the altar. To the left of the line are the men and to the right, the women, each singing different songs. The movement progresses inwards and to the right. 


\section{The musical form of the rice maiden's long journey}

What is the link between the musical performance and the content of the song? To answer that question, it is useful to understand how the narrative is performed. The organisation of the song is based on a clear assignment of musical tasks to specific performers.

In the haman opak bélun dance, the storyteller (opak) is introduced by his embroiderer (nukun opak) on an isochronous pulse. He chants the narrative while his embroiderer repeats the narrator's last words, adding a layer of vocal flourishes to the former's voice. After 100 lines of narrative, the storyteller takes a break and there is a lyric interlude sung by two duettists (named hodé ana'): two pairs of singers sing an identical musical phrase in alternation. This musical sequence contrasts with the preceding account of the story; now dancers shout enthusiastically, infusing energy into the dance, whereas the lyrics of the hodé ana' duets do not seem really meaningful. The first duo is called ana' puken ('children trunk'); the second duo, ana' wutun ('ending children'), repeats the words of the first. ${ }^{34}$ The duettists dance close to each other, so that the two pairs of singers form a unit. Within one pair, the first voice is called hodé' ('to receive'), while the second is called nuku ('second voice'). This sequence marks a rest during the narrative performance. After the hodé ana' duet sequence, there is sometimes a soloist, nukun blaha ('long second voice') or nukun ana' ('second voice child'), singing for a long period, following the story, as a kind of junior, second storyteller. Then, the main storyteller (opak) goes on again.

In the course of the sung performance, the 2,000-line narrative is constantly interspersed with lyrical breaks. One may wonder what the purpose of these breaks is. A singer explains:

Opak [storyteller] stops first, then comes hodé' ana' [duets]. They stop because people who listen are bored. In this dance, opak [storyteller] is paired with hodé' ana' [duets], alternating with nukun blaha [storyteller], in order to feel that night can last a little bit longer. (Bapa' Arnoldus Kebojan Maran, opak storyteller, Personal communication, January 2007)

34 There is a possibility of double meaning, suggested by a local performer, who told me that ana means 'songline' and not 'child' ( $a$ an'), which would make sense 'to receive the line' from the previous duet. 
In this quotation, boredom arises from narrativity, which may explain why these lyrical breaks do not advance the narrative; instead, they force a pause in the narrative. Perhaps, like a long walk on a hiking trail, the telling of the journey is inconceivable without breaks. Lyrical breaks in the great narrative repertoires are essential to the telling of the story, as if to highlight it, to relieve the narrator and to stimulate collective energy. What do these lyrical musical breaks actually tell us? During the rice maiden's journey, from line 1,462 to line 2,080, 25 narrative sequences sung by the storyteller are interrupted by 18 lyrical duet sequences (hodé' and') that occur almost every two minutes. Here is an example of an alternation between narrative sequence and what I call 'lyrical pause':

\section{The soloist narrative and embroiderer (opak + nukun opak)}

Duli Kaléba Lama diké

pali Lolon Lama Hadi

Matan nala noi

wekin nala lilé

Tonu wai' bui'

matan nala noi

wekin nala lilé

Tutu nala ema'

marin nala bapa'

péén nala bapa'
The site Kaléba Lama Diké

the site Lolon lama Hadi

[Pati Sadi] watches

he observes

Tonu looks

she watches

they observe each other

she [Nogo Ema'] tells to the mother

says to the father

to this father

\section{The duetting lyrical pause (hodé' ana')}

$\begin{array}{ll}\begin{array}{l}\text { Hajon é Béra } \\ \text { Raran tala Bama lali }\end{array} & \begin{array}{l}\text { Hajon e Béra } \\ \text { The road to Bama to the setting } \\ \text { sun } \\ \text { raran pi Bama ga'é }\end{array} \\ \text { Suban sepat to Waidoko is the road to Bama? } & \begin{array}{l}\text { Suban [male name] stops to see } \\ \text { Waidoko } \\ \text { Luhi pi malé ga'é }\end{array} \\ \begin{array}{ll}\text { Where is the thread for this } \\ \text { needle? }\end{array} \\ \end{array}$




\section{The soloist narrative and embroiderer (opak + nukun opak)}

Tonu néku tutu gokok

Wujo néku marin hajat

Nékun géte-géte

pai ahak data

Na’an léké létak

pai ama ahak dat tali

Nảan léké letak hala

taha tali hala

Nogo wekan lewo

Ema' dawin tana

péen dawin tana
Tonu comes back to talk

Wujo then speaks

Then questions

keeps questioning

They want to arrow her ${ }^{36}$

lure her with a rope

They do not arrow her

[she] cannot free herself from the rope

Nogo is shared in the village

Ema' is distributed on the land

distributed on this land

The duetting lyrical pause (hodé' ana')

Hajon Béra

Hajon! Béra!

These examples illustrate the whole process of singing narration. The link between the narrative and the duetting lyrical hodé ana' sequences seems rather loose. The hodé ana' duets tell about a village (Bama, Waidoko, line 1,773), but are also about thread and weaving_-perhaps as a comment on the narrative. They disconnect the narrative from the necessity of continuity and offer, through this semantic discontinuity, a poetic moment. These lyrical sequences may also sometimes interact as an echo and make it possible to value and resonate what has just been said. The flow of the song is structured by series of semantic and musical pauses that behave like narrative stopping points. Thus, the musical form itself expresses in a way the journey of the rice maiden, made by successive stops.

\section{The requirements of sung narrative performance}

Two criteria govern the singing of the journey: continuity and correct naming. On the one hand, the journey must be sung continuously; on the other, the storyteller must not make any mistakes in the itinerary.

36 The men want to shoot Tonu Wujo with an arrow, like a game animal. 
Only specialists can satisfy these requirements. Knowing how to set out the path in the right order without omitting any step is a challenge for all storytellers, who risk their lives in the event of performative error. I have shown elsewhere the importance of the persons in this society in charge of speech (whom we may call storytellers, chanters or master poets) (Rappoport 2016). Opak_called also bawa ('drum') or todo bawa ('to beat the drum continuously') — is the name of the storyteller, and is a title awarded to those who are able to sing long narrative sequences. As they have the capacity to memorise the genealogies and the routes of migration, these chanters are the guardians of custom. It is believed that they have an innate ability to recite the history of the ceremonial domains without having inherited it from the mouth of another and indeed without even being born in the place of which they sing.

The memory they demonstrate in singing and storytelling and their mastery of lexical complementarity are shared only by a small number of people. As a poetic element, lexical complementarity is a prerequisite of any kind of ritual speech.

The song itself says:

Tutu pali rala roi

marin rala kéna
To tell, they have to know to say, they must have knowledge ${ }^{37}$

Despite the fact that the storytellers are excellent singers and poets, these performers are viewed not as artists but rather as key persons in maintaining the harmony of society. Their responsibilities put them in danger should a performative fault occur, because words can influence the fate of the community. Their mission-mastering and performing ritual poetic narrative, thereby facilitating the reproduction of life-can lead to the performer's death. In eastern Flores, as in many places in the Austronesian world, these persons possess religious authority, which is expressed through the performance of ritual poetry considered as offerings to various kinds of spirits.

To sing the narrative is a cognitive skill that has a specific aim: to set out the path. However, should this path be wrong, danger might befall the community: 
We, as storytellers, tell of long journeys, from Larantuka, Ende or Maumere. I remember I was still a child when they rebuilt the great temple. They were dancing. One of the storytellers was from Belogili [a neighbouring village]. I moved to stand close to him. He was reciting. My father laughed: 'Ah, is this the right way or not? Is he acquainted with the temple or not?' After he returned home, two weeks later, he was dead. He did not know the [right] road. He knew a wrong road. We must know the way back. If we do not know it, we become lost. For example, [although] this way is said to be a good road, but it is a fire road, a wrong road. I was still in the second class of primary school, around 1959. (Storyteller Paulus Platin Maran, Personal communication, Waiklibang, 2010)

The idea of 'knowing the right road' is fundamental if one is to avoid being lost. To know the right path is to know the path of your ancestors. Not all the clans can tell the journeys. In this region, this task is exclusive to the sovereign clans (raja tuan) ${ }^{38}$ and, in particular, to the Maran clan, who are responsible for the poetic ritual speech (tutu marin: 'to say, to tell') before animal offerings. In the sociopolitical model of the region, four main clans (Koten, Kélen, Hurit and Maran) share sacrificial functions, with each of the names relating to their obligations during the killing of a pig (koten: 'head'; kélen: 'tail'; hurit: 'slice'; maran: 'pray'). The Maran clan's role as oral performers (singing, telling, praying) dates back to an ancestor who gave one of his sons the task of singing, speaking and telling the story by 'standing towards the sea and looking towards the mountain'-an expression meaning that these persons can speak to all the invisible spirits, both maritime (harin) and terrestrial (nitun). This distribution of mastery of public speaking is also found among their Sikka-speaking neighbours (Tana' Ai dialect), in whom it implies the attribution of a higher status to the clan responsible for the custodianship of the historical sequences relating to the ceremonial domain during the grén mahé ritual (Lewis 1988b: 98).

The narrative musical performance shows the need for completeness and the taste for musical breaks. This way of constantly interrupting the narrative raises the question of the relationship between space

38 At Waiklibang, the social structure comprises two types of clans: the sovereign clans (suku raja tuan) and the support clans (suku nipa talé). The former have the right and duty to make offerings to the land (buké tana). Penelope Graham (1991), who has done fieldwork in a neighbouring area (Lewotala), explains in detail the notion of clan in this part of Flores. 
(required by the narrative) and time (which music shapes). One could suggest that the length of the singing performance expresses the length of the journey. But let us turn the question around: what does the length of the journey tell us about time?

\section{The length of the rice maiden's road}

In the narrative of the rice maiden's journey, there is no linguistic marker of time and the Lamaholot expression for 'time' (ékan nuan) never appears. Instead, to express the idea of time, the song says:

$\begin{array}{ll}\begin{array}{l}\text { Tutu kala Bési kolé } \\ \text { marin kala Paré matan }\end{array} & \begin{array}{l}\text { Tell the Pumpkin stem } \\ \text { tell the Rice receptacle }\end{array} \\ \text { Bési kolé lewo doan } & \begin{array}{l}\text { The Pumpkin stem lies in } \\ \text { distant village } \\ \text { the receptacle of Rice is a } \\ \text { land }\end{array} \\ \text { paré matan tana léla } & \text { Far beyond a sea } \\ \text { Nian tasik ketiko to'u } & \text { far away like two rivers }\end{array}$

The meaning of these three distichs conveys the long distance from the rice's origin—a distance expressed by three spatial markers (doan, léla and nian), which signify 'far away' and two nouns, the river and the sea, which are two elements that, like time, are limitless and sourceless. This spatial distance possibly also means a great distance from the present. In addition, the idea of origin itself is suggested through the botanical metaphor (kolél matan: 'peduncle/receptacle'), referring to a stalk from which a flower emerges. Temporal depth through this narrative seems to be marked by space, as though there was no possibility other than to express the past through space.

The complementary pair kolélmatan ('peduncle/receptacle') deserves our full attention because, with other pairs, it expresses a framework of thought common all over Tanjung Bunga. It can be compared with another pair,

39 Line 112 and ff. In these distichs, various pairs are expressed: 1) tutu marin ('to tell, to say'), to talk ritually; 2) Bési paré ('Pumpkin rice'), rice; 3) Kolé matan ('stem receptacle'), a botanic metaphor referring to the origin; 4) lewo tana ('village land'), the ceremonial domain; 4) Tasik wai' ('sea river'), 'flooding'. 
which organises the vocal duets in this region, puken/wutun ('the trunk' and 'the tip'). In this region, vocal duets proceed in pairs. The first duo, the most expert, chooses the lyrics and the second completes them, using the same melodic-rhythmic motif. The first pair is called 'children of the trunk' (ana' pukén) and the second 'children of the tip' (ana' wutun). The first organises not only the singers, but also the song lyrics. It marks the importance, in their musical language, of the complementarity between anteriority (the one that begins) and posteriority (the one that follows). This ordering can be seen on three levels: at the level of a duet (one singer always starts before the other), at the level of the relationship between duettists (one duo always starts before another) and at the level of the spatialisation of the songs on the agricultural work lines (men sing a repertoire at the beginning and women sing another repertoire at the end of the harvest line).

These two complementary pairs (peduncle/receptacle and trunk/tip), which are prevalent in the field of orality (Fox 1988), indicate the need to respect an order of precedence. Why should this order of precedence be linked to the time of the rice maiden's journey? My hypothesis is that the perception of time in this region depends, in the general framework, on a relationship of authority organised in hierarchical pairs (between people, genders, clans and singers), between those who manage to associate the two ends of a story (the origin and the stem, the receptacle and its peduncle) and the two ends of a song, both literally and figuratively (able to tell the story and able to sing it; to begin and to end) (Rappoport In press).

Let us come back to space. In the narrative, time is imagined in terms of a path, according to the ceremonial domain that separates the place of enunciation from the place of origin, in a progression from the past to the singer's present. The progression is shown by the character's itinerary. The itinerary is told in the account of the journey, which is defined by the variety of places crossed-seas and rivers (tasik uai), ceremonial domains (lewo tana), fields and valleys (duli pali), large or small mountains (ilé bélen', wokan réren) —and encounters. The song's narrative consists, then, of telling the 'trace of the path':

Tutu kala Tonu ukut

marin kala Wujo raran
To tell the trace of Tonu ${ }^{40}$

to say the path of Wujo

40 Line 1,137 and $\mathrm{ff}$. 
Tonu ukut lewo doan

Wujo raran tana léla
The trace of Tonu lies in a distant village The path of Wujo is a remote land

James Fox (2006: 89) uses the term topogeny to refer to an ordered succession of placenames, showing that some Austronesian societies prefer topogeny to genealogy because successive generations are perceived only in space. One of the functions of these topogenies may be to establish the precedence of a group over a territory through the ability to store knowledge about the relationships and interconnections between past events and the secret names of spirits and places encountered during migration.

The temporal thickness may be perceived in the accumulation of places crossed, which requires time to be told and thus increases the length of the performance - a particularity of this kind of narrative - sung continuously for about five or six hours. A sort of homology can be established between the length of the performance and the length of the journey. We have seen above how the narrative is interspersed with interludes, within a continuous flow. About every hundred verses, the narration gives way to duets whose role is to pause in the story, like a pause on a path. Their function is not narrative but lyrical. While the essence of the song lies in its narrative, this song would not take place without these alternating duets that do not serve the narrative but help to rest, to endure the length of the path.

When music, at the time of agrarian rituals, calls to mind the myth of the origin of rice, singing no longer corresponds to a time lived in the present but calls to mind an ancient 'imagined' time. Everything that is told in the song is about the extraordinary: the communication with spirits, the metamorphosis of a maiden into an edible plant and the nonhuman ancestry of Tonu Wujo, born from the earthly spirits. Yet, during the telling of the myth, and for a whole agrarian year, from sowing to harvesting, one or two young women personify that seed. Through the ritual replaying the dramatic knot, the ancient time suddenly becomes actualised through a form of 'presentification'. It is as if the ritual, through storytelling and personification, makes the ancient times present. Thus, this myth of the origin of rice connects the personal history of clans to the arrival of rice in the region. 
Time lived and time represented are combined by myth — what Ricoeur (1983: 330) calls the intertwining of fiction and history. Indeed, the storyteller inscribes the ruling clans of the place of enunciation in the continuity of the imagined time by connecting them to Nogo Ema', the spirit of rice. The master poet connects himself to history by telling only of his own ancestors who met the rice maiden.

\section{Conclusion}

This chapter addressed the theme of the journey in the myth of the origin of rice. I have shown how the narrative rehearsed the journey of Nogo Ema', the maiden turned into rice, who travelled from west to east, from Li'o country to Tanjung Bunga. Her trip tells the story of the dispersal of rice in the eastern part of the island, to places that did not grow rice. This journey is distinguished by its length and also by its violence. Her ultimate destination is the village of the storyteller's family, some of whom may have known of the arrival of rice in the region.

This trip teaches something profound: in this society, as in many societies in eastern Insulindia, time is expressed by the recollection of the paths (in Lamaholot, ukut laran). The further away are these traces, the longer is the narrative. Only the storytellers know 'the traces of the paths', and this knowledge engages them vitally. For, to make a mistake in the enunciation of paths is to make a mistake about oneself and one's group. In these societies, orality is the only history book. We know how much a mistake in a history book can cost its author in Western societies, but in eastern Indonesia a mistake in stating the itinerary can bring death and illness to the group in question. Because the performance of these stories engages the bodies of the humans who tell them, it can be understood why the knowledge of roads and the ability to sing them are, in Lamaholot society, so important for the consciousness of the group.

\section{References}

Adams, Marie-Jeanne. 1971. 'Cultural variations in eastern Indonesia.' Manusia Indonesia 5(4-5-6): 425-40.

Berthe, Louis. 1972. Bei gua. Itinéraire des ancêtres. Mythe des Bunaq de Timor [Bei Gua: Route of the ancestors_Timor Bunaq myth]. Paris: Editions du CNRS. 
Eberhard, David M., Gary F. Simons and Charles D. Fennig, eds. 2020. Ethnologue: Languages of the world. 23rd edn. Dallas: SIL International. Available from: www.ethnologue.com.

Fox, James J. 1988. To Speak in Pairs: Essays on the ritual languages of eastern Indonesia. Cambridge Studies in Oral and Literate Culture. Cambridge: Cambridge University Press. doi.org/10.1017/CBO9780511551369.

Fox, James J. 2006. 'Genealogy and topogeny: Toward an ethnography of Rotinese ritual place names.' In James J. Fox, ed., The Poetic Power of Place: Comparative perspectives on Austronesian ideas of locality, pp. 89-100. Canberra: ANU E Press. doi.org/10.22459/PPP.09.2006.05.

Graham, Penelope. 1991. 'To follow the blood: The path of life in a domain of eastern Flores, Indonesia.' PhD dissertation, The Australian National University, Canberra.

Grimes, Charles, Therik Tom, Barbara Grimes and Max Jacob. 1997. A Guide to the People and Languages of Nusa Tenggara. Kupang: Artha Wacana Press.

Hatto, Arthur Thomas. 1980. Traditions of Heroic and Epic Poetry. Volume One: The traditions. London: The Modern Humanities Research Association.

Kohl, Karl-Heinz. 1998. Der Tod der Reisjungfrau: Mythen, Kulte und Allianzen in einer ostindonesischen lokal Kultur [The Death of the Rice Maiden: Myths, cults and alliances in an east Indonesian local culture]. Stuttgart: Kolhammer.

Kohl, Karl-Heinz. 2009. Raran Tonu Wujo: Aspek-aspek inti sebuah budaya lokal di Flores Timur [Raran Tonu Wujo: Core aspects of a local culture in eastern Flores]. Maumere: Penerbit Ledalero.

Kunst, Jaap. 1942. Music in Flores: A study of the vocal and instrumental music among the tribes living in Flores. Leiden: E.J. Brill.

Lewis, E. Douglas. 1988a. 'A quest for the source: The ontogenesis of a creation myth of the Ata Tana Ai.' In James J. Fox, ed., To Speak in Pairs: Essays on the ritual languages of eastern Indonesia, pp. 246-81. Cambridge: Cambridge University Press. doi.org/10.1017/CBO9780511551369.010.

Lewis, E. Douglas. 1988b. People of the Source: The social and ceremonial order of Tana Wai Brama on Flores. Dordrecht, the Netherlands: Foris Publications.

Mabuchi, Toichi. 1964. 'Tales concerning the origin of grains in the insular areas of eastern and Southeastern Asia.' Asian Folklore Studies 23(1): 1-92. doi.org/ $10.2307 / 1177638$. 
Pampus, Karl-Heinz. 2001. Mué moten koda kiwan: Kamus bahasa Lamaholot. Dialek Lewolema, Flores Timur [Mué moten koda kiwan: Lamaholot-Indonesian Dictionary, Lewolema Dialect, Eastern Flores]. Frankfurt am Main: FrobeniusInstitut.

Rappoport, Dana. 2009. Songs from the Thrice-Blooded Land: Ritual music of the Toraja (Sulawesi, Indonesia). Paris: Édition de la Maison des sciences de l'homme.

Rappoport, Dana. 2016. 'Why do they (still) sing stories? Singing narratives in Tanjung Bunga (eastern Flores, Lamaholot, Indonesia).' Wacana, Journal of the Humanities of Indonesia 17(2): 163-90. doi.org/10.17510/wacana.v17i2.439.

Rappoport, Dana. 2017. 'Singing in dangerous places (Flores, Lamaholot, Indonesia).' Asia Pacific Journal of Anthropology 18(5): 462-82. doi.org/ 10.1080/14442213.2017.1372515.

Rappoport, Dana. In press. 'Le temps de chanter. Pratiques musicales et perception du temps dans l'Est indonésien (Flores, Indonésie) [Time to sing: Musical practices and perception of time in eastern Indonesia (Flores, Indonesia)].' In Grégory Mikaelian, ed., Temporalités khmères: de près, de loin, entre îles et péninsules [Khmer Temporalities: Near, far, between islands and peninsulas]. Bern: Peter Lang.

Revel, Nicole. 2000. La quête en épouse. Une épopée palawan chantée par Mäsinu [The Quest for a Wife: Mämiminbin—A Palawan epic sung by Mäsinu]. Paris: Éditions UNESCO, Langues \& Mondes, L'Asiathèque.

Ricoeur, Paul. 1983. Temps et récit [Time and Narrative]. Paris: Seuil.

Tukan, Simon Suban. 1996. 'Masyarakat Lewolema dalam interpretasi mitos Nogo Ema' Besi Pare [The Lewolema society in the interpretation of the myth of the Nogo Ema' Iron Pare].' Masters thesis, Ledalero School of Philosophy, Flores, Indonesia.

van der Veen, Hendrick. 1965. The Merok Feast of the Sa'dan Toraja. The Hague: Martinus Nijhoff. doi.org/10.26530/OAPEN_613374.

van der Veen, Hendrick. 1966. The Sa'dan Toradja Chant for the Deceased. The Hague: Martinus Nijhoff. doi.org/10.26530/OAPEN_613381.

Vatter, Ernst. 1932. Ata kiwan: unbekannte Bergvölker im tropischen Holland [Ata Kiwan: Unknown hill tribes in tropical Holland]. Leipzig: Bibliographisches Institut.

Vatter, Ernst. 1963. Spiel und Tanz [Games and Dance]. (D828/1961). Göttingen, Germany: Institut für den Wissenshaftlichen film. 
This text is taken from Austronesian Paths and Journeys, edited by James J. Fox, published 2021 by ANU Press, The Australian National University, Canberra, Australia.

doi.org/10.22459/APJ.2021.07 